Dept. of Theriogenology,

Fac. Vet. Zagazig Univ., Benha Branch.

\title{
DEPENDENCY OF SOME REPRODUCTIVE PERFORMANCES IN MAGARABI FEMALE CAMELS (CAMELUS DROMEDARIUS)
}

(With 3 Tables)



** Dept. Theriogenology. Faculty of Vet. Med., El-Fateh Univ., Tripoli, Libya.

(Received at 9/9/1996)





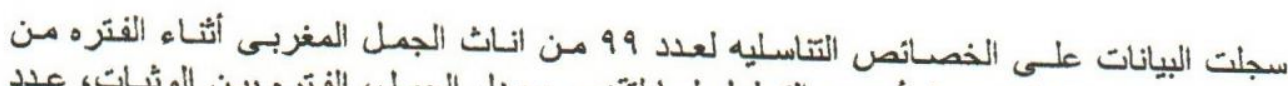



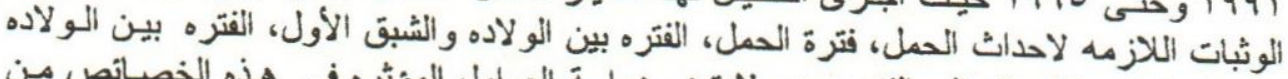

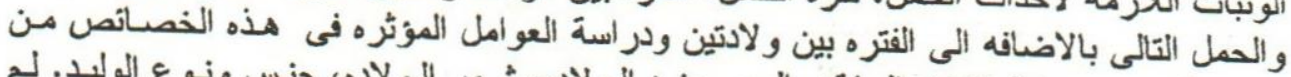





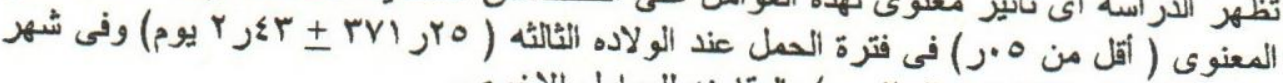

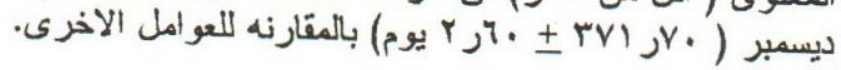

\section{SUMMARY}

Data obtained on the reproductive performances of 99 Magarabi female camels, during the period from 1991 to 1995, were analysed to estimate the conception rate, interval between services, number of service/conception, periods of gestation, from calving to the first postpartum heat and the open 
days as well as the calving interval. Dependency of these performances on effects of the breeding season, parity number, age at calving, month of calving, calf sex and weight was assessed. The present results did not find any significant effect for all these factors except on the gestation period which decreased significantly $(\mathrm{P}<0.05)$ at the third parity $(371.25 \pm 2.43$ days) and in December ( $371.70 \pm 2.60$ days) when compared to others.

Key words: Female Camels-Reproductive performances-parameters

\section{INTRODUCTION}

It has been found that the camel reproductive potential seems much lower when cpmpared to other breeds (Abdel-Rahim \& El-Nazier, 1992; Djellouli \& Saint-Martin, 1992). Attribution of the breeding seasonality, the 13-month gestation period and the approximately 2-year calving interval (Novoa, 1970; Musa, 1979; Hermas, et al., 1990; Arthur, 1992) constitute the major constraints to improve the reproductive capacity of camels. In libya, lack of keeping records on the camel reproductive patterns is a great handicap to establish a general policy for developing camels on the nation wide. Therefore, the present study was suggested to identify the normal reproductive performances of Magarabi camels and to assess their relation to some associated factors believed to have a possible effect.

\section{MATERIAL and METHODS}

The present study was conducted on a herd of Magarabi camels (Camelus dromedarius) kept at El-Assa Station, near the western territory of libya in the deep desert. Camels were fed on pasturing allround the year with the available green fodders (Nov.- March) or dry roughages and 2-3 kg concentrates (April-Oct.). Based on the daily observation, data on atol number of 99 female camels were collected throughout four breeding seasons from 1991 to 1995 . The data obtained were analysed to estimate the following:

1- The interval between services (days) within the same breeding season which annually starts at November first till April first.

2- The gestation period (days) from the last service to calving.

3- The postpartum period (days) elapsed from calving to onset of the first heat.

4- Open days period (days) from calving to the last successful service. 
5- Calving interval (days) elapsed between two consecutive calvings.

6- Rate of conception and number of service/conception.

In addition, to eliminating the effect of seasonality on these performances, some other factors were analysed as follow:

1- No. of parities: Only three parities were taken regarding age of the dam and size of the data.

2- Age of the dam at calving: less than 5yr; to less than $8 \mathrm{yr}$ and $8 \mathrm{yr}$ and over.

3- Month of calving from December to March which have big number of calvings.

4- Calf sex either male or female.

5- Calf weight (Kg); less than $30 \mathrm{~kg}, 30 \mathrm{~kg}$ to less than $35 \mathrm{~kg}$ and $35 \mathrm{~kg}$ or more.

Data obrained were tabulated and statistically computed by SAS (1986) to have the analysis of variance procedure and Duncan's Multiple Range test for performances in relation to the suggested factors.

\section{RESULTS}

The conception rate and number of services/conception averaged $39.06 \%$ and $3.55 \pm 0.19$ respectively. The conception rate varied from $29.51 \%$ to $44.79 \%$ between the breeding seasons. The latters did not reveal any significant difference in number of services/conception which varied from $3.78 \pm 0.51$ to $3.86 \pm 0.62$ (Table. 1 ).

In an overall means, the interval between services within the breeding season, periods of gestation, postpartum and open days as well as the calving interval were $15.83 \pm 0.39,379.23 \pm 0.89,28.30 \pm 2.63,288.98 \pm 11.99$ and $653.84 \pm 18.93$ days, respectively (Table. 2 ).

The present result did not reveal any significant effect to season of breeding, number of parity, age at calving, month of calving, calf sex and weight on the service interval, the postpartum period, the open days period and the calving interval. Only a significant $(\mathrm{P}<0.05)$ decrease in the gestation period was observed with the third parity (371.25 \pm 2.43 days) and in December ( $371.70 \pm 2.60$ days) when compared to other parities and months of calving, respectively (Table. 3 ).

\section{DISCUSSION}

As camels are seasonally polyestrus (Arthur, 1992) with short breeding season (Minoia, et $\underline{\text { al. }}$, 1992), long follicular cycle (Nawito, et al., 
1967) and require excessive number of services/conception (Table. 1). Thus, lowering the conception rate of camels has been anticipated. This anticipation was confirmed in the present study and in some previous reports (Novoa, 1970; Djellouli \& Saint-Martin, 1992) where the conception rate varied from 39 to $50 \%$. Such variation might be attributed to the combined action of location, management and nutritional conditions (Shareha, et al, 1982) that seem nearly constant among the different breeding seasons.

Since ovulation in the female camle is mainly induced by service (Novoa, 1970; Arthur, 1992), the present study hypothesized the interval between two services to express the estrous or follicular cycle (Nawito, et al., 1967). Such interval ranged from 10 to 28 days in the present study, a finding which agreed with some previous studies to vary from 11 to 35 days (Nawito, et al., 1967; Musa, 1979; Shareha, et al., 1982). However, the present study did not reveal any significant effect to those factors under investigation on the camel follicular cycle which might be of heriditary attribution.

From the present results, the gestation period in Magarabi camels averaged $379.23 \pm 0.89$ days. This finding came in consistent with some previous studies (Evans \& Powys, 1979 Hermas, et al., 1990; Arthur, 1992) where the gestation period in dromedaries varied from 365 to 395 days. The present study attributed such variations in the gestation period mainly to the prominant effects of the previous parturitions and month of calving. On the other hand, it has been observed that the majority of female camels calved at the beginning of a breeding season came into the first postpartum heat after approximately $26.34 \pm 1.89$ days within the same breeding season. This finding agreed with some previous studies (Novoa, 1970; Evans and Powys, 1979; Abdel-Rahim and El-Nazier, 1992) indicating that the pospartum heat occurs 14-30 days after calving. However, Hermas et al. (1990) notticed the pospartum heat in Magarabi camels to occur $233.97 \pm 14.90$ days after calving, and this might be due to the delay in estrous detection for the parturient females till the forthcoming breeding season. Nevertheless, the open day period elapsed from calving to conception in the present study (308.02 $\pm 6,95$ days) came relative to the value $(286.80 \pm 12,70$ days) estimated by Hermas et al. (1990). From this finding, it is of importance to notice that in camels even with the early induction of heat after calving, the majority of females fail to conceive within the same breeding season, and this might be due to effects of lactation, the feeding status or environmental stress (Shalash, 1965; Shareha et al., 1982 and Arthur, 1992).

Keeping in mind that the calving interval is the sum of open days and gestation periods, and as the gestation period is nearly constant for the 
individual, so, any increase in the open days period is reflected on the calving interval. The latter averaged $687.64 \pm 7.18$ days in the present study. This finding came nearly similar to $678.62 \pm 12.20$ days observed by Hermas et al. (1990) and lower than 2-3 years reported by others (Shalash, 1965; Minoia et al. (1992). Because the present study did not reveal any prominent effect to those factors under investigation on the periods from calving to the first postpartum heat and conception as well as the calving interval, it was difficult to conclude any recommendation aiming at imporving the camel productive and reproductive potential.

\section{REFERENCES}

Abdel-Rahim, S.E.A. and El-Nazier, A.T. (1992): Studeis on the sexual behaviour of the dromedary came... Proc. '-st Int. Camel Confr., 115-118.

Arhtur, G.H. (1992): An overview of reproduction in the camelids. Proc. 1st Int. Camel Confr. 109-113.

Djellouli, M.S. and Saint-Martin, G. (1992): Productivity and economy of camel Confr., 209-212.

Evans, J.O. and Powys, J.G. (1979): Camel husbandry to increase the productivity of ranchland. In: Camels. IFS Symp., Sudan, 241-250.

Hermas, S.A.; Shareha, A.M. and Abusaud, F. (1990): Reproductive performance of Magarabi Camel (Camelus dromedarius). Camel Res. Centre, Tripoli, Bull. 1990, PP: 133-143.

Minoia, P.; Moslah, M.; Lacalandra, G.M.; Khorchani, T. and Zarrilli, A. (1992): Induction of estrus and management of reproduction in the female dromedary camel. Proc. 1st Int. Camel Confr., 119-123.

Musa, B.E. (1979): Reproductive patterns in the female camel (Camelus dromedarius). Vet. Rec., 103: 556-557.

Nawito, M.F.; Shalash, M.R.; Hoppe, R. and Rakha, A.M. (1967):

Reproduction in female camel. National Res. Centre, Cairo, Bull. 2, PP: 16-19.

Novoa, C. (1970): Reproduction in camelidae. J. Reprod. Fertil, 22: 3-20.

SAS (1985): Statistical analysis system, user's guide: statistics, $1985 \mathrm{Ed}$, cary, Nc: SAS Inst. Inc., PP: 433-506.

Shalash, M.R. (1965): Some reproductive aspects in female camel. World. Rev. Anim. Prod. 1: 103-107. 


\section{Assiut Vet. Med. J. Vol. 36 No. 72, January 1997}

Shareha, A.M.; Magdoub, A.B. and Zaied, A.A. (1982): Investigation on reproductive perfcormance of the female camel (Al-NAGA) Camelus dromedarius. Libyan J.ric., 11: 43-45.

Table (1): Rate of conception and number of service per conception for the female camels in different breedind seasons.

\begin{tabular}{|c|c|c|c|c|c|}
\hline \multirow{2}{*}{ Performances } & \multicolumn{4}{|c|}{ BREEDIND SEASONS } & \multirow[t]{2}{*}{ Total } \\
\hline & $91-92$ & $92-93$ & $93-94$ & $94-95$ & \\
\hline Total females No. & 61 & 96 & 38 & 61 & 256 \\
\hline Females conceived & 19 & 43 & 14 & 25 & 100 \\
\hline Conception rate & 29.51 & 44.79 & 36.84 & 40.98 & 39.06 \\
\hline No. of servive / & $3.78^{a}$ & $3.19^{\mathrm{a}}$ & $3.86^{2}$ & $3.84^{2}$ & $3.55^{2}$ \\
\hline conception & \pm 0.51 & \pm 0.92 & \pm 0.62 & \pm 0.32 & \pm 0.19 \\
\hline
\end{tabular}

* Means \pm S.E.

Letters in the same raw indicates non significant differences.

Table ( 2 ): Range and overall means of some reproductive performances in Magarabi femle camels.

$\begin{array}{llll}\text { Performances } & \begin{array}{l}\text { No. of } \\ \text { observations }\end{array} & \text { Range } & \text { Mean } \pm \text { S.E }\end{array}$

$\begin{array}{lccc}\text { Service interval (days) } & 139 & 10-28 & 15.83 \pm 0.39 \\ \text { Gestation period (days) } & 139 & 353-398 & 379.57 \pm 0.81 \\ \text { Post-partum period (days) } & 47 & 10-72 & 26.34 \pm 1.89 \\ \text { Open days period (days) } & 42 & 222-375 & 308.02 \pm 6.95 \\ \text { Calving interval (days) } & 42 & 601-757 & 687.64 \pm 7.18\end{array}$


Table ( 3 ): Effects of some factors on reproductive performances of Magarabi female camels (Mean + S.E).

\begin{tabular}{lccccc}
\hline \multicolumn{2}{|c|}{ Performances } & G. P. & P.P. & O. D. & C. I. \\
\hline Factors & $\begin{array}{c}\text { S. I. } \\
\text { (days) }\end{array}$ & $\begin{array}{c}\text { (days) } \\
\text { (days) }\end{array}$ & (days) & (days) \\
\hline
\end{tabular}

Breeding season:

$91-92 \quad 14.19 \pm 0.67^{2} 378.88 \pm 1.57_{a}^{2} 32.00 \pm 13.35^{2} 309.77 \pm 17.89^{2} 643.36 \pm 49.87^{2}$

$92-93 \quad 16.67 \pm 0.99^{2} 383.57 \pm 3.53_{2} 24.00 \pm 04.5 l_{2}^{2} 290.43 \pm 16.18^{2} 669.57 \pm 27.30^{2}$

$93-94 \quad 15.55 \pm 0.6 f_{a}^{A} 379.90 \pm 1.84^{2} 25.31 \pm 02.1 l_{2}^{2} 264.50+45.24_{2}^{a} 642.00 \pm 46.49^{a}$ $94-95 \quad 61.32+0.81^{a} 379.22+2.22^{2} 35.00+07.84^{2} 302.06 \pm 18.47^{\lambda} 682.13+19.15^{\circledR}$

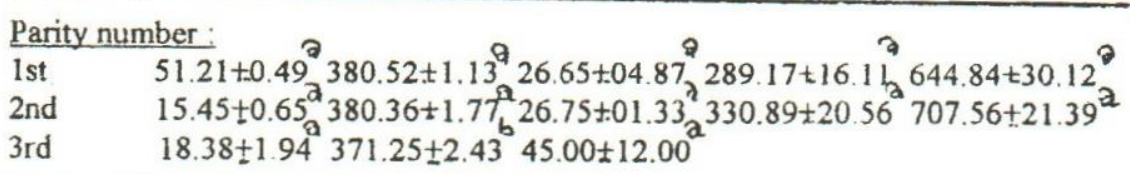

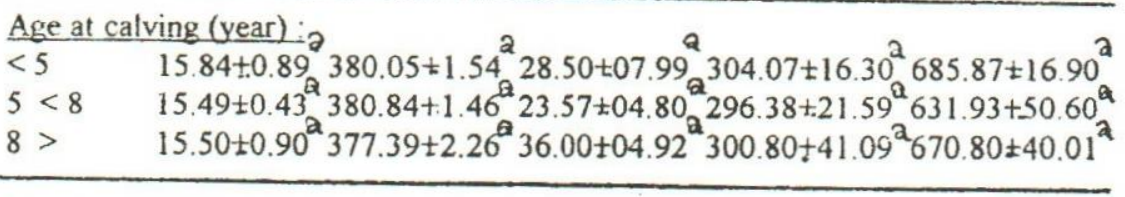

Month of calving: $\quad 15.00 \pm 0.82^{2} 371.70 \pm 2.60^{b} 37.50 \pm 12.18^{2} 321.00 \pm 44.15^{a} 670.80 \pm 40.01^{2}$

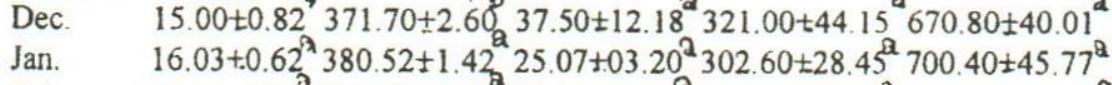
Feb. $\quad 15.90 \pm 0.84^{a} 380.77 \pm 2.04^{a} 24.20 \pm 05.03^{a} 291.33 \pm 33.66^{a} 623.55 \pm 64.67^{a}$ March $14.53 \pm 1.04^{a} 380.71 \pm 1.99^{2} 35.00 \pm 08.01^{a} 294.92 \pm 10.25^{2} 667.50 \pm 34.71^{a}$

Calf sex:

Male $14.97 \pm 0.53^{\mathrm{a}} 380.78 \pm 1.38^{\mathrm{a}} 24.33 \pm 01.79^{\mathrm{a}} 295.94 \pm 17.84^{\mathrm{a}} 636.29 \pm 18.16^{\mathrm{a}}$ Female $16.12 \pm 0.60^{\mathrm{a}} 378.83 \pm 1.35^{\mathrm{a}} 31.00+05.67^{\mathrm{a}} 305.44+17.73^{\mathrm{a}} 646.59 \pm 22.11^{\mathrm{a}}$

Calf weight $(\mathrm{kg})$ :

$<30 \quad 15.57 \pm 1.35^{2} 378.58 \pm 2.50^{2} 23.50 \pm 0330^{\mathrm{a}} 323.60 \pm 18.55^{\mathrm{a}} 701.60 \pm 22.31^{\mathrm{a}}$ $30<35 \quad 16.03 \pm 0.59_{a}^{a} 380.45 \pm 1.45_{a}^{a} 32.45+07.72^{\alpha} 297.36+16.99^{a} 634.87+45.85^{a}$ $35>\quad 15.07 \pm 0.55379 .27 \pm 1.43^{a} 25.50 \pm 01.77^{a} 295.50 \pm 23.46^{a} 675.57 \pm 24.22^{\mathrm{a}}$

Different letters in the same column for the same factor are $\mathrm{P}<0.05$ Values are expressed in Mean +S.E

Different letters in the same column for the same factor are $\mathrm{P}<0.05$. Values are expressed in Mean + S.E.

S.I $=$ Service intervals. G.P. $=$ Gestation period.. etc.

P.P. $=$ Post - partum.

O.D. $=$ Open days.

C.I. $=$ Calving interval. 
